\title{
Yvette Veyret (sous la direction de), 2003, Les risques.
}

Paris, SEDES, 2003, 255 p.

Jean-Pierre Husson

\section{OpenEdition}

\section{Journals}

Édition électronique

URL : http://journals.openedition.org/rge/2423

DOI : $10.4000 /$ rge.2423

ISSN : 2108-6478

\section{Éditeur}

Association des géographes de l'Est

Édition imprimée

Date de publication : 1 juin 2003

ISSN : 0035-3213

\section{Référence électronique}

Jean-Pierre Husson, «Yvette Veyret (sous la direction de), 2003, Les risques. », Revue Géographique de

l'Est [En ligne], vol 43 / 3 | 2003, mis en ligne le 01 décembre 2010, consulté le 25 septembre 2020.

URL : http://journals.openedition.org/rge/2423 ; DOI : https://doi.org/10.4000/rge.2423

Ce document a été généré automatiquement le 25 septembre 2020.

Tous droits réservés 


\section{Yvette Veyret (sous la direction de), 2003, Les risques.}

Paris, SEDES, 2003, 255 p.

Jean-Pierre Husson

\section{RÉFÉRENCE}

Yvette Veyret (sous la direction de), 2003, Les risques. Paris, SEDES, 2003, 255 p.

1 Les risques, objet social inscrits dans les relations nature-société, représentent un champ de recherche et de réflexion pluridisciplinaire passionnant. Cette question actuellement inscrite parmi les sujets mis aux concours, permet à Y. Veyret entourée d'une dizaine de collaborateurs, de produire un manuel qui offre des éclairages représentatifs et bien choisis pour balayer cette thématique. L'ouvrage s'organise en quatre parties. Il débute par un énoncé de la diversité des risques placés entre l'aléa, le déclenchement, la gestion voire l'anticipation par les acteurs, enfin les choix de zonage effectués pour circonscrire. La seconde partie fournit des éclairages qui déclinent les risques dans les pays en développement, avec en particulier le risque alimentaire en Afrique (question qui croise le sujet posé en géographie régionale) et la prévention au Bengladesh trop souvent malmené par d'immenses inondations. La troisième partie traite de façon thématique ou régionale des risques rencontrés dans les pays riches et égrène la diversité des réponses apportées. Enfin, deux chapitres sont consacrés aux risques économiques et sociaux. Au total, ce manuel analyse clairement la variété des scénarios du déroulement des risques appréhendés dans des échelles emboîtées, dans un souci d'énoncé global. Il invite également à réfléchir sur le couple disparité/ solidarité qui domine la planète. 


\section{AUTEURS}

JEAN-PIERRE HUSSON

Université Nancy 2 